\title{
Diagnosis of Fusarium keratitis in an animal model using the polymerase chain reaction
}

\author{
George Alexandrakis, Shahram Jalali, Peter Gloor
}

\begin{abstract}
Aims/background-The purpose of this study was apply the polymerase chain reaction (PCR) to develop a sensitive, specific, and rapid test to diagnose Fusarium keratitis. Fusarium is the most common cause of fungal corneal infection in some parts of the world. It is often difficult to establish that a keratitis is due to fungal infection.

Methods-Fusarium solani keratitis was induced in three eyes of three rabbits by injection of a suspension of the fungus into the anterior corneal stroma. In one rabbit the contralateral eye served as a control. From four to 28 days after inoculation, the corneas were scraped for culture, then scraped and swabbed for PCR analysis. The PCR was performed with primers directed against a portion of the Fusarium cutinase gene, and the presence or absence of this amplified target sequence was determined by agarose gel.

Results-The amplified DNA sequence was detected in 25 of 28 samples from the corneas infected with Fusarium, for a sensitivity of $89 \%$. Only three of the 14 samples from these eyes with Fusarium keratitis were positive by culture, for a sensitivity of $21 \%$. Seven of eight control samples were negative by the PCR based test, for a specificity of $88 \%$.

Conclusion-This PCR based test holds promise of being an effective method of diagnosing Fusarium keratitis as well as Fusarium infections at other sites.

(Br F Ophthalmol 1998;82:306-311)
\end{abstract}

Department of

Ophthalmology and

Visual Science, Yale

University School of

Medicine, New Haven,

Connecticut, USA

G Alexandrakis*

S Jalali

P Gloor

${ }^{\star}$ Current address: Bascom Palmer Eye Institute,

University of Miami School of Medicine, Miami, FL 33101, USA.

Correspondence to: Peter Gloor, MD, Department of Ophthalmology and Visual Science, Yale University School of Medicine, PO Box 208061, New Haven, CT 06520-8061, USA.
In some parts of the world, fungal infection accounts for over one third of corneal ulcers. ${ }^{1}$ Fusarium, a genus of filamentary fungus, is the most common cause of fungal keratitis in parts of the southern United States and Africa. ${ }^{2-8}$ Corneal infections with filamentary fungi occur predominantly in healthy, young men with a history of outdoor, ocular trauma. ${ }^{1-489}$

The diagnosis of fungal keratitis continues to be problematic. Fungal ulcers can have feathery, hyphate edges, raised borders, a white or greyish colour, satellite lesions, and an associated endothelial plaque. ${ }^{389}$ However, many fungal ulcers demonstrate no striking morphological pattern. ${ }^{110}$ Since many of these characteristics are not specific to fungal ulcers, the literature recommends that antifungal therapy be withheld until diagnosis is confirmed by laboratory studies. ${ }^{79}$ Gram and Giemsa stains of corneal scrapings have sensitivities of about $50 \%$ in establishing the diagnosis. ${ }^{134811}$ Fun- gal cultures from corneal scrapings often take 3 to 4 days, and can take weeks, to become positive. ${ }^{1811}$ Culture has been used as the "gold standard" for the diagnosis of fungal keratitis, so true sensitivity of culture is unknown. ${ }^{48}$ The laboratory diagnosis of fungal keratitis may be problematic because of the very small sample which can be obtained by scraping a corneal ulcer.

The polymerase chain reaction (PCR) technique permits the in vitro copying and recopying of a selected DNA sequence in a series of denaturation, reannealing, and extension steps in the presence of synthetic oligonucleotide primers and heat stable DNA polymerase. ${ }^{12}{ }^{13}$ This allows amplification of a target sequence to concentrations which are easily detectable by conventional laboratory methods. When applied to the detection of infection, the PCR is extremely sensitive and can establish the presence of even a few organisms in a sample. The amplification occurs if and only if the target DNA sequence is in the reaction mixture. Therefore, with careful selection of the target sequence, the PCR can be a highly specific test. A PCR based test can be accomplished in a few hours, and so is much more rapid than culture. PCR amplification has been successfully applied to the diagnosis of viruses, bacteria, and protozoa from the ocular surface, corneal buttons, aqueous samples, and vitreous samples. ${ }^{14-23}$

We have developed a PCR based test which detects a portion of the Fusarium genome and have applied it to confirm the diagnosis of a Fusarium panophthalmitis in postmortem tissues. $^{24}$ In this study, we investigated the potential for use of this PCR based test in the diagnosis of active Fusarium keratitis. We applied the test to samples collected from experimentally induced corneal ulcers in rabbits.

\section{Materials and methods}

ANIMAL MODEL OF FUSARIUM KERATITIS

Two strains of Fusarium solani, isolated from patients with fungal keratitis were obtained as lyophilised pellets (strains S-432, S-446; Fusarium Research Center, Penn State, University Park, PA, USA). The fungi were passaged on Sabouraud's dextrose agar plates at room temperature, and an inoculum was prepared by suspending harvested spores in sterile yeast peptone broth.

Adult, male New Zealand albino rabbits were anaesthetised with an intramuscular injection of $5 \mathrm{mg} / \mathrm{kg}$ xylazine and $40 \mathrm{mg} / \mathrm{kg}$ ketamine. Using a portable slit lamp, a syringe with a 30 gauge needle was inserted 
tangentially into the central corneal stroma to a depth of about one third of the corneal thickness. ${ }^{25}$ About $50 \mu \mathrm{l}$ of the inoculum, the equivalent of 50000 Fusarium spores, were injected.

A Fusarium solani keratitis was induced in one eye of each of three rabbits. Two of these eyes also received $1.0 \mathrm{mg}$ of subconjunctival triamcinolone acetonide subconjunctivally at the time of inoculation. The contralateral eye of one of these rabbits served as a control. It was first inoculated with sterile peptone broth, and 14 days later a Candida albicans corneal ulcer was induced as described for Fusarium. All animal research was approved by an institutional review and conformed with the guidelines of the Yale University Animal Use and Care Committee.

SAMPLE COLLECTION AND PREPARATION

Sample collection was performed four or five times during the period from 4 to 28 days after inoculation. The rabbits were anaesthetised as described above. A Kimura spatula was thoroughly flamed and then cooled with sterile water before each scraping. Using the portable slit lamp and the spatula, the base of the corneal ulcer (or the injection site in the case of the control eye to the end of day 12) was scraped using the Kimura spatula. The material obtained was minimal and in most samples not visible on the spatula tip. The cornea was initially scraped for culture on Sabouraud's dextrose agar plates with gentamicin. The cornea was then scraped for the PCR, and the spatula was stirred for a few seconds in $150 \mu \mathrm{l}$ of deionised, sterile water in a $1.5 \mathrm{ml}$ sterile Eppendorf tube. Finally, the cornea was swabbed for PCR using a Rayon swab. The swab was placed in $150 \mu \mathrm{l}$ of deionised, sterile water in a $1.5 \mathrm{ml}$ sterile Eppendorf tube. The Sabouraud's plates were incubated at room temperature for 4 weeks.

All samples obtained from the rabbit corneas for PCR were stored at $-20^{\circ} \mathrm{C}$ for up to 4 weeks until processing. They were initially thawed to room temperature. In order to release DNA from any spores, the entire sample was heated in the thermal cycler (Ericomp, San Diego, CA, USA) at $100^{\circ} \mathrm{C}$ for 15 minutes, and then the specimens were chilled on ice. The swabs were discarded from those samples obtained with swabs. Three aliquots, 1-35 $\mu$, were taken from each sample and each aliquot placed directly into a separate PCR mixture.

POLYMERASE CHAIN REACTION PROTOCOL The oligonucleotide primers used for the PCR $^{12}$ were sequences complementary to a 189 base pair portion of the Fusarium solani cutinase gene. ${ }^{26} 27$ The primers had the following sequences:

5' -ATC GAG GAC CTC GAC TCG- 3'

5' -GCA GCA ACG ATC AAG CTA- 3'

Each $50 \mu \mathrm{l}$ PCR mixture contained 10 $\mathrm{mmol} / 1$ TRIS- $\mathrm{HCl}(\mathrm{pH} 8.4), 50 \mathrm{mmol} / 1 \mathrm{KCl}$, $1.5 \mathrm{mmol} / 1 \mathrm{MgCl}_{2}, 200 \mathrm{mmol} / \mathrm{l}$ of each of all four deoxyribonuleoside triphosphates, 2.5 units of Taq polymerase (Promega), $75 \mathrm{pmol}$ each of the oligonucleotide primers, and an aliquot from the corneal samples.

Using the "hot start" method to improve specificity, samples were kept at $80^{\circ} \mathrm{C}$ for $2-3$ minutes and then the deoxyribonuleoside triphosphates were added to each sample. ${ }^{28}$ Samples were initially denatured for 7 minutes at $94^{\circ} \mathrm{C}$, and then subjected to 37 cycles of amplification using the following variables: denaturation at $94^{\circ} \mathrm{C}$ for 60 seconds, annealing at $55^{\circ} \mathrm{C}$ for 70 seconds, and extension at $72^{\circ} \mathrm{C}$ for 100 seconds. After the last cycle, samples were incubated for 10 minutes at $72^{\circ} \mathrm{C}$. Standard methods were followed in order to avoid false positive results caused by PCR product carryover. $^{29}$

A positive and negative control were included for every set of PCRs. For the positive control, the sample consisted of the purified Fusarium solani DNA extracted from fresh mycelium (see below). For the negative control, the sample consisted of deionised, sterile water.

DETECTION OF THE PCR PRODUCT

A volume of $8 \mu \mathrm{l}$ of each amplification reaction was analysed by electrophoresis on a $1.8 \%$ agarose gel and the DNA fragments were visualised by staining with ethidium bromide. If the positive and negative controls did not yield the expected results, the results of the run were considered invalid, and the run repeated.

The presence or absence of the target DNA fragment after PCR amplification was also confirmed using Southern blot hybridisation with a 5 ' biotin labelled internal probe. ${ }^{14}{ }^{30}$ The probe had the following sequence 5' -AGATCGCCGGAACTGTTCTGTTCGGC TACA- 3'. The product was detected using a streptavidin-alkaline phosphatase conjugate dephosphorylation reaction system.

Restriction mapping of the amplified target sequence DNA was performed by digesting the purified 189 base pair PCR product with the restriction endonucleases Sty1, BsaJ1, or EcoO109I. The digestion products analysed on agarose gel.

DNA PREPARATION FOR CONTROL SAMPLES DNA was extracted from fresh mycelium grown on Sabouraud's dextrose agar plates by lysis for 1 hour at $65^{\circ} \mathrm{C}$ in a $50 \mathrm{mM}$ TRIS- $\mathrm{HCl}$ (pH 7.2) buffer containing $50 \mathrm{mM}$ EDTA, 3\% SDS, and 1\% 2-mercaptoethanol. The DNA was purified by phenol-chloroform extraction repeated three times, followed by ethanol precipitation. The pellet was suspended in deionised, sterile water and aliquots were used as a positive control for each PCR run.

Purified DNA samples from other species causing infectious keratitis were isolated in order to determine the specificity of the PCR based test. Cultures of other fungi, bacteria, and viruses which commonly cause infectious keratitis were well characterised clinical isolates provided by a clinical department of microbiology. For Fusarium oxysporum (strain O-783, Fusarium Research Center, isolated from a patient with mycotic keratitis), Aspergillus fumigatus, Penicillium, and Candida albicans, 


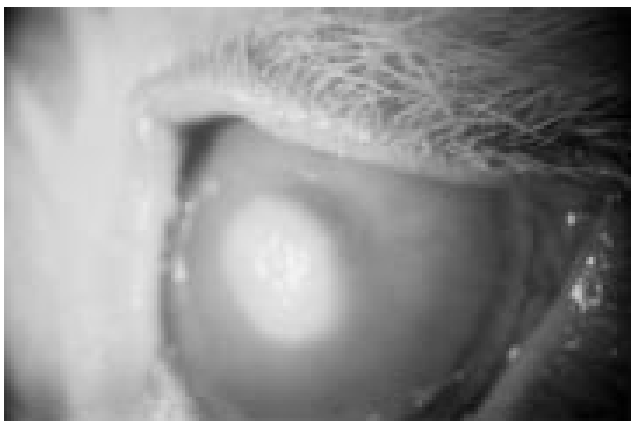

Figure 1 A rabbit cornea 5 days after inoculation with Fusarium solani, showing a focal infiltrate and diffuse corneal oedema.

DNA was extracted and purified as described above. DNA was extracted from Staphylococcus aureus, Pseudomonas aeruginosa, Streptococcus pneumonia, and herpes simplex, as previously described. ${ }^{14} 19$ In addition, a scraping from human buccal mucosa was processed in the same manner as the rabbit cornea scrapings.

\section{Results}

ANIMAL MODEL OF FUSARIUM KERATITIS

Using the procedures described above, severe Fusarium solani infections were apparently induced. Two to 4 days after inoculation with Fusarium, a 2-4 mm central infiltrate appeared at the inoculation site, and the peripheral cornea became oedematous (Fig 1). By day 8 peripheral vascularisation began. By day 12 the stromal infiltrate had progressed to the surface to produce an epithelial defect with some stromal thinning, and the vessels had grown into the infiltrate (Fig 2). By days 24-28 the infiltrate was subsiding, and a 3-4 $\mathrm{mm}$ vascularised scar began to form. The injection of subconjunctival triamcinolone at the time of inoculation delayed the inflammatory signs for a day or two, but the subsequent inflammation was greater than in the eye in which no corticosteroid was used.

Injection of the control eye with sterile peptone broth produced no inflammatory signs. When the same eye was subsequently inoculated with Candida albicans, inflammatory signs, similar in their course to that described for Fusarium, ensued (Fig 3).

PCR AND CULTURE RESULTS

Twenty eight PCR samples (15 scrapings and 13 swabs) were obtained from corneas inoculated with Fusarium solani and eight samples

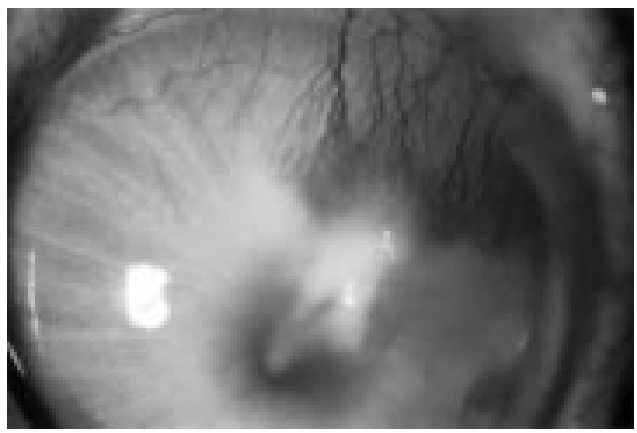

Figure 2 A rabbit cornea 12 days after inoculation with Fusarium solani, showing vascularisation of the infiltrate.

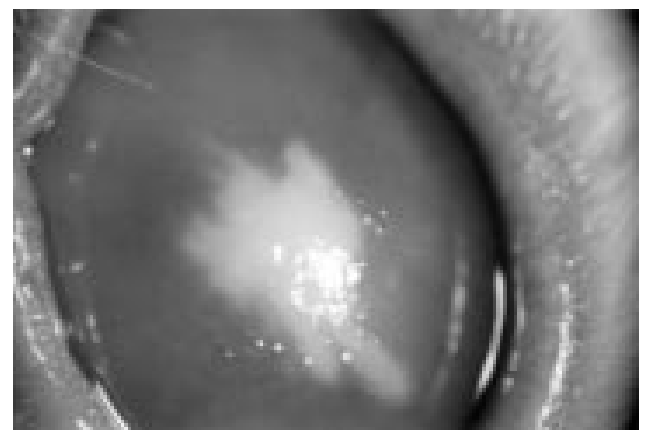

Figure 3 A rabbit cornea 4 days after inoculation with Candida albicans, showing a focal infiltrate and diffuse corneal oedema.

(four scrapings and four swabs) were obtained from the control eye. A sample was considered positive by the PCR method if and only if one or more of the three aliquots yielded a PCR product visible as a band of expected size on agarose gel electrophoresis (Fig 4).

The presence of the target DNA was detected in 25 of the 28 samples from corneas inoculated with Fusarium solani (Table 1). Assuming that all samples collected from Fusarium inoculated corneas were infected with Fusarium when the samples were collected, the sensitivity of the technique was $89 \%$. Scrapings and swabs gave similar results. Target DNA was also amplified in one of the eight control samples, for a specificity of $88 \%$. All negative results and all but two positive results by agarose gel were confirmed by Southern blot analysis.

Only three of the 14 cultures of scrapings from Fusarium infected corneas plated on Sabouraud's dextrose agar grew Fusarium, for a sensitivity of $21 \%$. All positive cultures were from within the first 13 days after inoculation of the cornea. For each positive culture, fungal colonies grew within 3 days of sample collection. For all samples that were positive by culture, the corresponding PCR samples were both positive. There were no false positive cultures, for a specificity of $100 \%$.

LIMITS OF DETECTION AND SPECIFICITY

The identity of the 189 base pair PCR amplification product was confirmed by restriction endonuclease digestion. The restriction enzymes produced fragments of the expected sizes (Fig 5).

In order to establish the limits of detection of this PCR technique, amplifications of serial dilutions of Fusarium solani spores suspended in deionised, sterile water were performed. Using the same sample preparation and PCR protocols as those described for the rabbit corneal specimens, the PCR was able to amplify the fragment of the cutinase gene from as few as 10 Fusarium spores to levels detectable by agarose gel (Fig 6).

Homologies between the cutinase gene primers and other known DNA sequences were excluded by a computer analysis of all sequences available in GenBank (June 1993; Genetics Computer Group, Madison, WI, USA). Specificity of the PCR assay was further tested by conducting PCR amplifications with 


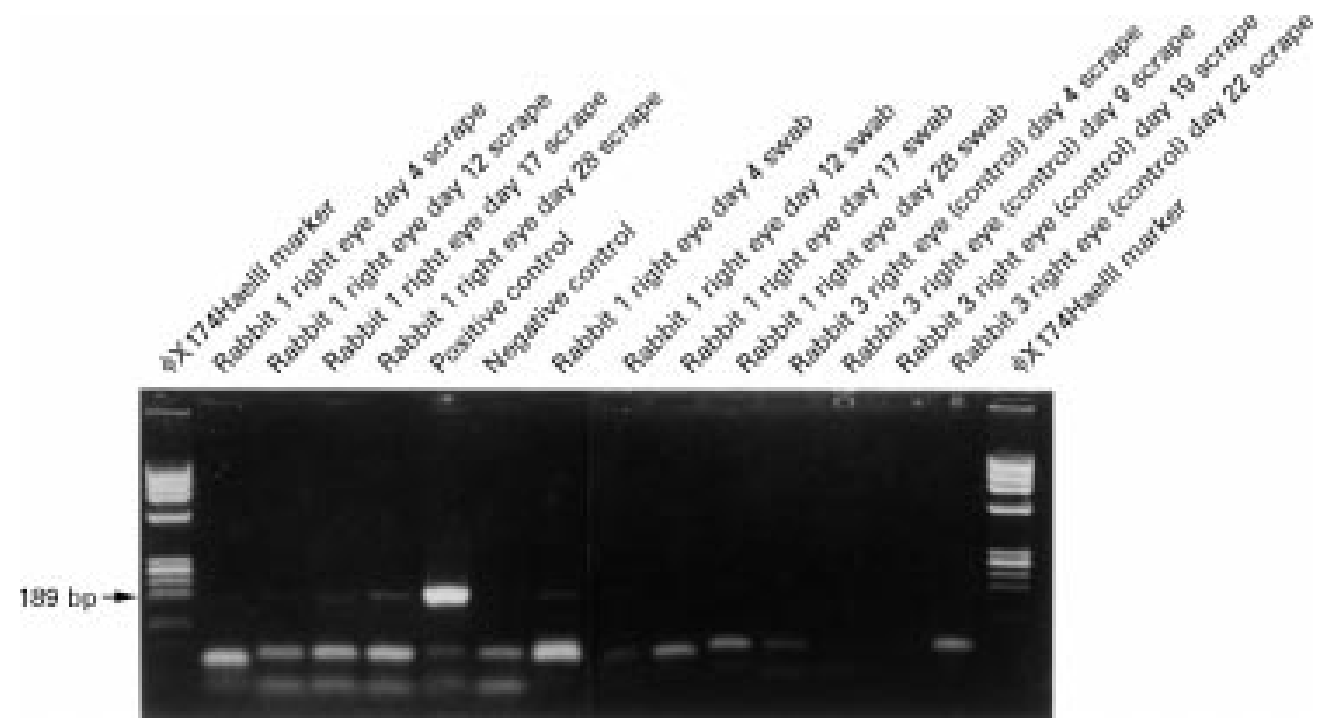

Figure 4 Agarose gel showing PCR results of samples collected by scraping and swabbing Fusarium infected and control corneas. Many of the positive results from the Fusarium infected eyes consist of only faint bands of the target fragment of the cutinase gene, which are lost on reproduction of the photograph. However, the faint bands were confirmed by Southern blot analysis. As expected, the PCR products from the control eye contained no detectable target DNA. A separate negative control was from the PCR performed at the same time with sterile water substituted for the sample. The positive control was PCR product from purified DNA extracted from fresh Fusarium mycelium.

purified extracted DNA from non-Fusarium samples, using the cutinase gene primers and the same PCR protocol. DNA isolated from Aspergillus fumigatus, Penicillium, Candida albicans, Staphylococcus aureus, Pseudomonas aeruginosa, Streptococcus pneumonia, and herpes simplex failed to result in the amplification of the 189 base pair fragment by both agarose gel analysis and Southern blot hybridisation. A scraping from human buccal mucosa, which contained human cells (and probably a variety of bacteria), also yielded negative results. The PCR test did amplify the target sequence when performed with purified Fusarium oxysporum DNA extracted from mycelium.

\section{Discussion}

In this preliminary study, our PCR based test was evaluated for its efficacy in the detection of Fusarium keratitis from corneal scrapings and swabs in an animal model of fungal keratitis. If it is assumed that the corneas inoculated with Fusarium solani were infected with the organism at all times that samples were collected (our "gold standard"), the PCR based test was significantly more sensitive than culture in the detection of Fusarium infection. The PCR based test had a sensitivity of $89 \%$, compared with $21 \%$ for culture.

One explanation for this difference is that a culture is positive only if the sample contains viable organisms, while a PCR based test will detect both viable and non-viable organisms. A PCR test can be positive even if only a single copy of the target DNA is present. ${ }^{31}$

In studies of human keratitis, about one third of all cultured corneal ulcers are culture negative, ${ }^{132}$ so it is unknown how many fungal ulcers go undiagnosed by currently available culture techniques. Blood agar, Sabouraud's media, and thioglycolate are the only media commonly used in the examination of ulcers that are likely to yield positive fungal cultures. The combination of these three media had a sensitivity of less than $50 \%$ among culture positive fungal corneal ulcers in a study that used additional media. ${ }^{11}$ Although many fungal cultures from corneal infections can become positive within 72 hours of sample collection, about one fourth become positive only after 2 weeks. ${ }^{1811}$ Among the cases of human fungal keratitis, Gram and Giemsa stains have sensitivities of only $25 \%$ to $66 \%$ in different series. $^{2} 34811$ Given the sensitivity of the PCR test and the fact that it could be completed within 4 hours of sample collection, the test has the potential to become a very useful test in the diagnosis of Fusarium.

Although the PCR based test was four times more sensitive than culture, three samples from Fusarium infected corneas were negative. All

Table 1 Summary of culture and polymerase chain reaction (PCR) results

\begin{tabular}{|c|c|c|c|c|c|c|c|c|c|c|c|c|c|c|c|c|c|}
\hline \multirow[b]{2}{*}{ Rabbit } & \multirow[b]{2}{*}{ Eye } & \multirow[b]{2}{*}{$\begin{array}{l}\text { Inoculation } \\
\text { on day } 0\end{array}$} & \multicolumn{3}{|l|}{ Day 4} & \multicolumn{3}{|c|}{ Days 5-12 } & \multicolumn{3}{|c|}{ Days $13-17$} & \multicolumn{3}{|c|}{ Days $18-21$} & \multicolumn{3}{|c|}{ Days $22-28$} \\
\hline & & & Culture & $\begin{array}{l}\text { Scrape } \\
\text { PCR }\end{array}$ & $\begin{array}{l}\text { Swab } \\
P C R\end{array}$ & Culture & $\begin{array}{l}\text { Scrape } \\
\text { PCR }\end{array}$ & $\begin{array}{l}\text { Swab } \\
P C R\end{array}$ & Culture & $\begin{array}{l}\text { Scrape } \\
\text { PCR }\end{array}$ & $\begin{array}{l}\text { Swab } \\
P C R\end{array}$ & Culture & $\begin{array}{l}\text { Scrape } \\
P C R\end{array}$ & $\begin{array}{l}\text { Swab } \\
P C R\end{array}$ & Culture & $\begin{array}{l}\text { Scrape } \\
P C R\end{array}$ & $\begin{array}{l}\text { Swab } \\
P C R\end{array}$ \\
\hline 1 & $\mathrm{R}$ & Fusarium $^{\star}$ & - & + & + & + & $+/+$ & + & - & + & + & & & & $-/-$ & + & + \\
\hline 2 & $\mathrm{~L}$ & Fusarium & + & + & + & - & + & + & - & + & + & - & + & + & & & \\
\hline 3 & $\mathrm{~L}$ & Fusarium $^{\star}$ & - & $-x$ & + & - & $-x$ & $-x$ & + & $+/+$ & + & - & + & + & - & + & + \\
\hline 3 & $\mathrm{R}$ & Control $\dagger$ & - & - & - & - & - & - & & & & - & - & - & - & - & $+x$ \\
\hline
\end{tabular}

^These eyes received $1 \mathrm{mg}$ of subconjunctival triamcinolone at the time of inoculation.

tThe control cornea was injected with broth on day 0 and then Candida on day 14 .

+ Indicates a positive result for the presence of Fusarium by culture or PCR; - indicates a negative result for the presence of Fusarium by culture or PCR; -x indicates a false negative PCR result; $+x$ indicates a false positive PCR result. 


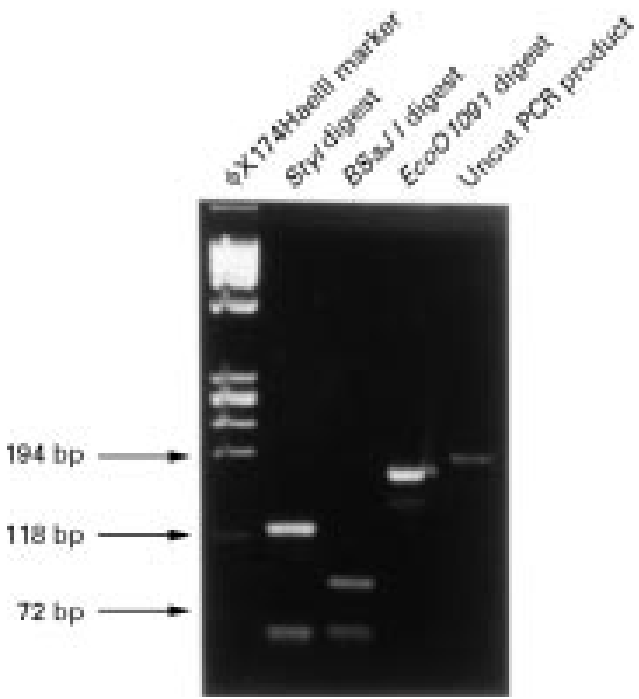

Figure 5 Agarose gel of restriction endonuclease digests of the PCR product. Fragments of the expected sizes were produced (Sty1: 122 base pair (bp) and 67 bp; Bsaf1: 87 $b p, 67 b p$, and $35 \mathrm{bp}$; EcoO109I: $174 \mathrm{bp}$ and $15 \mathrm{bp}$ ), confirming that the product was the target fragment of the Fusarium cutinase gene.

false negative samples were obtained from the same corticosteroid treated Fusarium eye during the period of 4 to 9 days after inoculation. Since corticosteroid administration suppressed the clinical response to infection by filamentary fungi, ${ }^{33}$ it is possible that the infection was not sufficiently superficial to obtain an adequate sample. Another possibility is that the inflammatory response to the infection damaged the Fusarium DNA or otherwise inhibited the PCR.

The specificity in our series was only $88 \%$, due to a single false positive. Contamination from the contralateral Fusarium infected eye is the most likely explanation for the false positive. Although standard methods were followed during all procedures in order to avoid PCR product carryover, ${ }^{29}$ contamination dur-

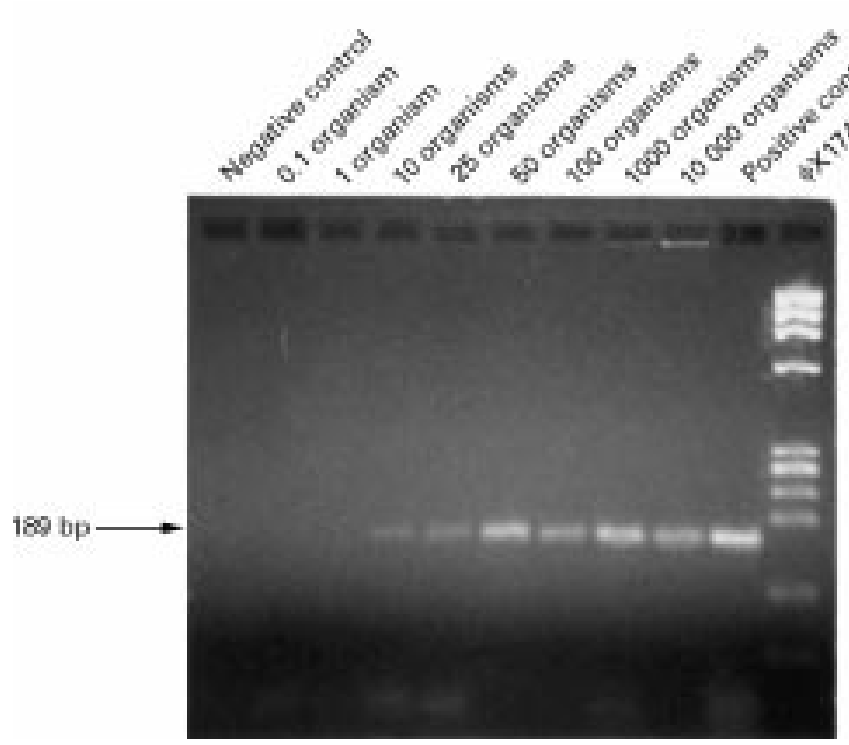

Figure 6 Agarose gel of PCR products from a serial dilution of Fusarium solani spores, demonstrating that this PCR based test can detect from 10 to 10000 organisms in a sample. Positive and negative controls are as described in Figure 4. ing the preparation of the PCR samples is another possibility.

We chose a fragment of the cutinase gene as our target DNA because we felt it could be specific to Fusarium but conserved within the genus. Cutinases are excreted by phytopathogenic fungi and catalyse the hydrolysis of the structural polyester of the plant cuticle and so are important to the survival of the fungus. ${ }^{26} 27$ The test was able to detect Fusarium oxysporum as well as Fusarium solani. We also demonstrated that applying the Fusarium PCR based test to other corneal infectious agents, including other fungi, bacteria, and herpes simplex, yields negative results.

In this study, all specimens obtained from Fusarium infected eyes during the fourth week after inoculation were positive for the target DNA, although the corneal ulcers appeared to be nearly healed and cultures were negative. This may be an illustration of the fact that PCR based tests for infection will be positive whenever the sample contains a sufficient number of copies of the target DNA, whether the organisms are dead, constitute normal surface flora, or are causing an active infection.

Our technique involved only boiling of the PCR samples and adding aliquots directly to the PCR mixture without any purification steps. This is a convenient and rapid method of DNA preparation, reduces the risk of contamination, and eliminates the DNA loss which would occur from attempting DNA purification. Releasing DNA from filamentary fungi is problematic since these organisms have resilient cell walls. Boiling for 15 minutes apparently releases the fungus DNA without damaging the cutinase gene sufficiently to inhibit the PCR. Further refinement of the sample preparation for the PCR may improve the sensitivity of the test.

This PCR based test holds promise to be an effective method of diagnosing Fusarium keratitis in the clinical setting. Compared with standard laboratory techniques, it offers increased sensitivity as well as a significant reduction in the time required to establish the diagnosis. However, further studies are needed to refine the technique, improve its sensitivity and specificity, and to establish the value of the technique in managing patients with corneal ulcers. Systemic fungal infection is becoming an increasingly common infection among iatrogenically immunosuppressed patients, where the diagnosis is also problematic. ${ }^{34-37}$ Therefore, the technique may eventually have wide application in the diagnosis of fungal disease.

Presented at the Association for Research in Vision and Ophthalmology annual meeting, Sarasota, FL, USA, 3 May 1994.

This study was supported by a student fellowship award, in memory of Norma Newman Cohen, from the Fight for Sight Research Division of the National Society to Prevent Blindness (GA) and a grant from Research to Prevent Blindness (PG). The authors thank Sandy Waycott at the Department of Microbiology of Yale University for providing the clinical isolates. They thank John Danias, $\mathrm{MD}, \mathrm{PhD}$, and Iqbal Ahmad, They also thank Marvin L Sears, MD for providing the laboratory facilities.

1 Liesegang TJ, Forster RK. Spectrum of microbial keratitis in south Florida. Am f Ophthalmol 1980;90:38-47. 
2 Jones DB, Sexton RR, Rebell G. Mycotic keratitis in south Florida: a review of 39 cases. Trans Ophthalmol Soc UK Florida: a review

3 Jones DB, Wilson L, Sexton RR, Rebell G. Early diagnosis of mycotic keratitis. Trans Ophthalmol Soc UK 1970;89. 805-13.

4 Forster RK, Rebell G. The diagnosis and management of keratomycosis. I Cause and diagnosis. Arch Ophthalmol 1975;93:975-8.

5 Gugnani HC, Talwar RS, Njoku-Obi ANU, Kodilinye HC. Mycotic keratitis in Nigeria. Brf Ophthalmol 1976;60:60713.

6 O'Day DM. Selection of appropritae antifungal therapy. Cornea 1987;6:238-45.

7 Johns KJ, O'Day DM. Pharmacologic management of keratomycoses. Surv Ophthalmol 1988;33:178-88.

8 Rosa RH, Miller D, Alfonso EC. The changing spectrum of fungal keratitis in south Florida. Ophthalmology 1994;101: fungal ker-13.

9 Polack FM, Kaufman HE, Newmark E. Keratomycosis. Medical and surgical treatment. Arch Ophthalmol 1971;85: Medica

10 Asbell P, Stenson S. Ulcerative keratitis. Survey of 30 years' laboratory experience. Arch Ophthalmol 1982;100:77-80.

11 O'Day DM, Akrabawi PL, Head WS, Ratner HB. Laboratory isolation techniques in human and experimental fungal infections. Am F Ophthalmol 1979;87:688-93.

12 Saiki RK, Scharf S, Falloona F, et al. Enzymatic amplification of $\beta$-globin genomic sequences and restriction site analysis for diagnosis of sickle cell anemia. Science 1985;230:1350-4

13 Mullis KB, Falloona F. Specific synthesis of DNA in vitro via a polymerase-catalyzed reaction. Methods Enzymol 1987;155:335-50.

14 Kaye SB, Lynas L, Patterson A, et al. Evidence for herpes simplex viral latency in the human cornea. $\mathrm{Br} \mathcal{F}$ Ophthalmo 1991;75:195-200.

15 Fox GM, Crouse CA, Chuang EL, et al. Detection of herpesvirus DNA in vitreous and aqueous specimens by herpesvirus DNA in vitreous and aqueous specimens by the polym 266 .

16 Talley AR, Garcia-Ferrer F, Laycock KA, Loeffelholz M, Pepose JS. The use of polymerase chain reaction for the detection of chlamydial keratoconjunctivitis. Am f Ophthalmol 1992;114:685-92.

17 McDonnell JM, McDonnell PJ, Sun YY. Human papillomavirus DNA in tissues and ocular surface swabs of patient with conjunctival epithelial neoplasia. Invest Ophthalmol Vi Sci 1992;33:184-9.

18 Cantin E, Chen J, Willey DE, Taylor JL, O'Brien WJ Persistence of herpes simplex virus DNA in rabbit corneal cells. Invest Ophthalmol Vis Sci 1992;33:2470-5.

19 Nishi M, Hanashiro R, Mori S, Masuda K, Mochizuki M, Hondo R. Polymerase chain reaction for the detection of varicella-zoster with acute retinal necrosis. Am f Ophthalmol 1992;114: with -9.
20 Yu DD, Lemp MA, Mathers WD, Espy M, White T. Detection of varicella-zoster virus DNA in disciform keratitis using polymerase chain reaction. Arch Ophthalmol 1993; 111:167-8.

21 Aouizerate F, Cazenave J, Poirier L, et al. Detection of Toxoplasma gondii in aqueous humour by the polymerase chain reaction. Br f Ophthalmol 1993;77:107-9.

22 Yamamoto S, Shimomura Y, Kinoshita S, et al. Detection of herpes simplex virus DNA in human tear film by the polymerase chain reaction. Am f Ophthalmol 1994;117: $160-3$.

23 Su CS, Bowden S, Fong LP, Taylor HR. Detection of hepatitis B virus in tears by polymerase chain reaction. Arch Ophthalmol 1994;112:621-5.

24 Alexandrakis G, Sears M, Gloor P. Postmortem diagnosis of Fusarium panophthalmitis by polymerase chain reaction. Fusarium panophthalmitis by poly

25 Forster RK, Rebell G. Animal model of Fusarium solani keratitis. Am f Ophthalmol 1975;79:510-5.

26 Soliday CL, Flurkey WH, Okita TW, Kollattukudy PE. Cloning and structure determination of $\mathrm{cDNA}$ for cutinase, an enzyme involved in fungal penetration of plants. Proc Natl Acad Sci USA 1984;81:3939-43.

27 Soliday CL, Dickman MB, Kolattukudy P. Structure of the cutinase gene and detection of promoter activity in the 5'-flanking region by fungal transformation. $\mathcal{F}$ Bacteriol 1989;171:1942-51.

28 Nuovo GJ. The hot-start polymerase chain reaction. In: PCR in situ hybridization: protocols and applications. New

29 Kwok S, Higuchi R. Avoiding false positives with polymerase chain reaction. Nature 1989;339:237-8.

30 Southern E. Detection of specific sequences among DNA fragments separated by gel electrophoresis. F Molec Biol 1975;98:503-17.

31 Innis MA, Gelfand DH, Sninsky JJ, White TJ. Isolation of DNA from fungal mycelia and single spores. In: PCR protocols: a guide to methods and applications. San Diego: Academic Press, 1990:286.

32 McDonnell PJ, Nobe J, Gauderman WJ, et al. Community care of corneal ulcers. Am $\mathcal{F}$ Ophthalmol 1992;114:531-8.

33 O'Day DM, Ray WA, Head WS, Robinson RD, Williams TE. Influence of corticosteroids on experimentally induced keratomycosis. Arch Ophthalmol 1991;109:1601-4.

34 Richardson SE, Bannatyne RM, Summerbell RC, et al. Disseminated fusarial infection in the immunocompromised host. Rev Infect Dis 1988;10:1171-81.

35 Cho CT, Vats TS, Lowman JT, Brandsberg JW, Tosh FE. Fusarium solani infection during treatment for acute leukemia. F Pediatr 1973;83:1028-31.

36 Anaissie E, Kantariian $\mathrm{H}$, Ro J, et al. The emerging role of Fusarium infections in patients with cancer. Medicine 1988;67:77-83.

37 Minor RL, Pfaller MA, Gingrich RD, Burns LJ. Disseminated Fusarium infections in patients following bone marrow transplantation. Bone Marrow Transplant 1989;4:653-8. 